\title{
Development of accessories from reusable knitwear
} waste

See end of the paper for authors' affiliations

\section{KAUR}

Department of Apparel and

Textile Science, College of Home Science, Punjab Agricultural

University, LUDHIANA (PUNJAB)

INDIA

Email : devinderct@pau.edu
ABSTRACT : The investigation entitled development of accessories from reusable knitwear waste was carried out in Ludhiana city. An interview schedule was prepared for the purpose of collection data from 90 respondents between the age group of 17-27 years selected through purposive random sampling technique from three colleges of Ludhiana city. The results of the study revealed that majority of the respondents were 17-22 years of age group and were higher secondary, belonging to nuclear families and had monthly family income ranged between Rs. 50,000-75,000. Seventy one per cent of the respondents were aware of accessories prepared from reusable knitwear waste and 53.33 per cent were interested to reuse the knitwear waste whereas, 65.56 per cent of the respondents preferred to buy accessories. Crocheted accessories were the most preferred accessories with two coloured combination followed by multi and three coloured combinations. Most of the fabric waste was collected from factories. On the basis of the preferences of respondents, two sketches of each accessory were developed through Corel Draw X4 and were shown to 15 panel of judges. After the selection of sketches the most preferred designs were developed. After this second interview schedule was prepared to study the preferences for the developed accessories. For this purpose same sample of ninety respondents were selected. All the accessories were highly appreciated on the basis of suitability of design, utility and overall impact. Majority of the respondents rated all the accessories as very good. The quoted prices of the accessories were found to be adequate and 11.00 to 81.92 per cent profit can be earned by making accessories.

KEY WORDS: Accessories, Crocheted, Reusable, Sketches, Knitwear

- HOW TO CITE THIS PAPER : Kakkar, N. and Kaur, D. (2015). Development of accessories from reusable knitwear waste. Asian J. Home Sci., 10 (1) : 33-40. 